\title{
The Corporate Reputation of Islamic Banks: A Measurement Scale
}

\author{
Jaafar A. M. Almahy ${ }^{1}$, Farid Al-Sahn ${ }^{2} \&$ Ahmed Beloucif ${ }^{3}$ \\ ${ }^{12}$ College of Business, University of Bahrain, Kingdom of Bahrain \\ ${ }^{3}$ Aberdeen Business School, United Kingdom \\ Correspondence: Jaafar Almahy, College of Business, University of Bahrain, Bahrain. E-mail: \\ g_elmahi@yahoo.com
}

Received: June 24, 2014 Accepted: September 9, $2014 \quad$ Online Published: November 24, 2014

doi:10.5539/ijms.v6n6p91 URL: http://dx.doi.org/10.5539/ijms.v6n6p91

The study is sponsored by the Deanship of the College of Scientific Research, University of Bahrain.

\begin{abstract}
During the last few years, the concept of corporate reputation has received considerable attention from marketing academics and practitioners alike. This is not surprising in view of the concept enormous practical implications. Suffice it to say, that the market value of a modern company lies mainly in its intangibles assets. Corporate reputation embodies all of the intangible capital that a company may have. The current study describes an attempt to develop and validate a scale to measure the corporate reputation of Islamic banks. The operational definition of the construct draws mainly on its attitudinal and perceptual nature. To tap into the different dimensions of the target domain, an initial item pool of 42 statements was developed following a comprehensive review of related literature. Successive stages of revision, editing, rewriting and face and content validity reduced the initial item pool to 29 statements. These were put to a convenient sample of 150 bank customers in the Kingdom of Bahrain. The resultant data set was factor analyzed. A Principal Component Analysis extraction method suggested a two factor solution. Between them, the two factors explained $55 \%$ of the total variance in the factor model. Items that loaded poorly on any of the two components were eliminated from the analysis. 17 items made up the final version of the scale. The Cronbach alpha coefficients revealed that the two subscales and the overall scale were reliable. The inter-item correlation coefficients, the variance extracted, the factor communalities, and the Cronbach alpha coefficients do all point to the validity of the construct: that all the items in the scale seem to measure an underlying theme, in this case the corporate reputation of Islamic banks.
\end{abstract}

Keywords: corporate reputation, Islamic banks, measurement scale, content validity, reliability, pool of items

\section{Introduction}

The emergence of Islamic banking on the world stage in the early 1970s of the last century represented something of a paradigm shift in international finance.Muslims, it was thought, would at last, have an Islamic financial system that appeals to their Islamic ideals, offers them free-interest finance, promotes social justice and welfare, and stresses social responsibility in commercial and business practices; a viable alternative to the debt-based mode of finance advocated by western financial institutions.

Soon after, Islamic financial institutions fanned out to all four corners of the world. Every Islamic country now has a considerable Islamic component in its banking sector. In some countries like Iran, Pakistan, and the Sudan, for instance, the whole financial sector is molded in the image of Islamic finance.More than that, conventional banks in non-Muslim countries like U.K., Germany, Switzerland and many more are also embracing the Islamic model of finance by adding the so-called 'Islamic windows' to their existing banking operations (Amboch, 2008; Eagle, 2006; Sharif, 2006; Ranzini, 2007).

As of now, there are more than 500 Islamic financial institutions operating worldwide with an asset value in excess of a trillion dollar (Etzod et al., 2011).

\section{Research Objectives}

The Islamic financial model appeared to be particularly relevant in the aftermath of the recent global financial meltdown. As the crisis unfolds, financial experts around the world started to have a second hard look at the model. After all, Islamic financial institutions appeared to be immune to the turbulences that the conventional 
financial system had endured (Al-Hamazani, 2008). As important western financial institutions collapsed one after the other during the turmoil, proponents of the Islamic model of finance including some western writers were actively promoting the model as an effective cure for the woes and sins of conventional finance.

Yet, despite its impressive expansion and growth, the industrystillaccounts for a mere one percent of the global financial market (Dawood, 2008). Today, the Islamic banking industry is a 40-year old phenomenon. Throughout this time, no Islamic bank, for instance, broken into the top 100 global brands, competing with (the likes of) Coca-Cola, Citibank, and Google (Financial Islam, 2010).

A number of problems and challenges seemed to have prevented the industry from realizing its full potential in becoming an important player in global finance (Wilson, 1999, 2000; Khan \& Bakhti, 2009). Chief among these challenges is a perception and reputational problem (Ahmed, 2010). For the vast majority of Muslims having a financial system that adheres to the principles and goals of Islamic Sharia is a lofty ideal they all aspire and subscribe to. As such, they have wholeheartedly embraced the idea and many of them became active participants in it. However, the practice of some Islamic financial Institutions has in certain cases casts long shadows of doubts on the credibility and integrity of the experiment to the extent that some Muslims began to have serious misgivings in dealing with Islamic banks and other financial institutions. Many industry experts, academics and some renowned Muslims scholars subscribe to this view (Zaman, 2002; Dusuki \& Abdalla, 2006; Ambah, 2008; Bhatti, 2010).

Zaman (2002) for example claimed that, "Islamic banking has not yet made any significant contribution to the economies of the countries in which they operate, or to the evolution of a new financial system that incorporates Islamic principles of equality and fair play in financial dealings" (p. 1). He went on to question the claims of conformity to Islamic economic precepts by the operators of these banks. To him these banks, "mimic some of the worst banking practices of conventional financial institutions" and in that "they are neither serving the cause of banking and finance, nor that of Islam" (Zaman, 2002, p. 1). Nasser et al. (1999) found that Islamic banks customers are not fully satisfied with the Islamic products despite more branches are opened by conventional banks operating in accordance with the Islamic Sharia principles.

Ambach cited the collapse of the Islamic bonds market (Sukuk) in Bahrain in 2008 as evidence of the confusion and bad investment decisions that plagued the industry (Ambach, 2008). An editorial in the online Islamic Finance went further to accuse Islamic banks of being product pushers, including conventional products wrapped in an Islamic wrapper. This, according to the article, eroded the authenticity and integrity of these banks. "If, these banks", the article continued, "offer an Islamic mortgage with the same down payment, tenor, and profit rate as a conventional mortgage," a Muslim is entitled to ask (what is the difference?)" (2010, p. 2).

Along the same line of argument, Dusuki and Abdulla (2006) wrote "evidence on current practices by Islamic banks worldwide suggests that the majority of financing operations are not based on equity. Rather, Islamic banks have consistently favored the use of debt-based models of financing" (p. 1). This according to the two writers "poses suspicions amongst unconvinced Muslims and other critical outsiders who observe that Islamic banks, in reality are not different from conventional banks". Hence, "there are reasons to believe that the ideal structure of Islamic banks based on Profit-Loss Sharing (PLS) principles may indeed prove to be a mirage ... By far the most common financing method is debt-based instruments like Murabaha, which may simply be a backdoor to riba" (p. 1). A director at the Islamic Bank of Britain (IBB) quoted by the Times (UK) claimed that Sharia-compliant banking products failed to take off in Britain. "I am sad to finally admit that Islamic finance in UK has been a huge flop", the industry expert added. IBB, "may still be limping on as probably the last bastion of the cause, but it is difficult to imagine it holding out any longer ...Competitors have fared even worse and many had closed or scaled back their operations significantly" (Bhati, 2010).

The foregoing debate provided the main catalyst for this study.The way Islamic banks are viewed and perceived by their Muslim clients seems to be an important research question that warrants a formal investigation.This study represents the first step in answering this question. It sets out to achieve two related goals. These are:

(a) Develop and purify a scale measuring the corporate reputation of Islamic Banks.

(b) Validate the scale on a separate sample of banks' customers.

\section{The Islamic Financial Model: The Theological Underpinnings}

The roots of Islamic finance are to be found in the set of rules and laws which regulate the economic, social, political and cultural life of Muslims be it at the individual or the societal level. These rules and laws originate from the holy Quran and its subsequent interpretation by the Prophet Mohamed and Muslim scholars (Hassan \& Lewis, 2007). Within this context, some of the basic principles of an Islamic finance are, (a) the prohibition of 
interest designated in Arabic as 'riba', (b) risk sharing; (c) money should be looked upon as potential capital not a commodity; (d) the prohibition of speculative market behavior; (e) capital must have a social and ethical purpose beyond pure, unfettered return (f) investments in businesses dealing with alcohol, gambling, drugs or anything that Shari'ah considers unlawful are deemed undesirable and prohibited.

The term 'riba' indicates 'an excess' of capital or more precisely, any positive, fixed, predetermined rate tied to the maturity of the principal regardless of the performance of the investment-. The prohibition of riba in Islam is based on the arguments of social justice, equality and the prevention of exploitation of other people misfortunes. Islam forbids the charging of interest and encourages the earning of profits for the simple reason that profits, determined ex post, symbolize successful entrepreneurships and the creation of wealth, while interest, determined ex ante, is a cost that is accrued irrespective of the outcome of the business operations (Igbal \& Mirkhor, 2013).

The sharing of risk among borrowers and lenders relate to the premise that suppliers of funds shall become investors rather than creditors. I.e. the provider of funds and the entrepreneur share business risks in return for a share in profits.

The prohibition of speculative market behavior is directly related to the meaning of money in Islam which is radically different from that found in western economies. In Islam, money does not constitute a commodity in and of itself. It can only be regarded as so when invested in productive economic activities and hence the creation of wealth. As one Islamic expert puts it, "in Islamic finance you cannot make money out of thin air". "Our (financial) dealings have to be tied to actual economic activity, like an asset or a service" "You cannot make money out of money. You have to have a building that is actually purchased, a service actually delivered, or a good that was actually sold", (al-Faisal, 2008). With this mind, speculative market behavior, hoarding, excessive risk-taking are discouraged if not forbidden.

To realize these goals, the Islamic financial system has managed to come up with a number of financial products and services based on the principle of profit-loss sharing (PLS) or what is known as equity financing. These include the financial instruments of Murabaha (cost-plus financing); Mudarabah (profit-sharing); Ijarah (leasing); Musharaka (partnership) and bay alsalam (forward selling). The adoption of these instruments by the Islamic financial institutions should for the needs of Muslims worldwide and addressed their concerns in their in their financial dealings. Table 1 provides a definition of each of these instruments.

Table 1. The Islamic financial products

\begin{tabular}{|c|c|}
\hline Name & Meaning \\
\hline Murabah & $\begin{array}{l}\text { An instrument that describes the financing of goods and services where the financial } \\
\text { institution purchases these on behalf of the customer. }\end{array}$ \\
\hline Musharakah & $\begin{array}{l}\text { Full-equity partnerships where the provider of funds and the entrepreneur directly and wholly } \\
\text { share in the business. }\end{array}$ \\
\hline Mudarabah & $\begin{array}{l}\text { The provision of capital to a partial-equity partnership in return for a share of profits, but } \\
\text { where the losses on funds lent are borne by the lender. }\end{array}$ \\
\hline Bai muajjall & Deferred payments on products encompassed under Murabaha. \\
\hline Istisna & $\begin{array}{l}\text { Or manufacturing contracts to cover work in progress and paid by the financial institution on } \\
\text { behalf of the customer. }\end{array}$ \\
\hline Ijarah & Lease financing in form of operating leases only. \\
\hline Takaful & Or Islamic insurance in the form of cooperative self-help schemes. \\
\hline Quardhassan & Benevolent loans offered interest free. \\
\hline Bai Al-Salam & Advance or pre-paid sale contracts of goods and services. \\
\hline
\end{tabular}

Source: Gait\& Worthington (2008).

\section{The Scale Development Process}

The process of scale development is well documented in the literature (Churchill, 1979; Clark et al., 1995; Vellis, 2003). This process would look like the following:

(a) Develop a precise and detailed conception of the target construct. This is normally done against the backdrop of a thorough review of the relevant and related literature.

(b) The creation of an item pool. A fundamental goal here is to sample systematically most of the content that is potentially relevant to the target construct. 
(c) Purify the measure (conduct face and content validity).

(d) A collection of data from a well chosen sample.

(e) Assess the different facets of the scale reliability.

(f) Assess scale validity.

These steps offer a useful framework that would guide the discussion in the remainder of this research paper.

\subsection{Concept of Corporate Reputation}

The increased interest in corporate reputation within the last decades has resulted in a flurry of studies on the meaning, antecedents and outcomes of the construct. This is not surprising given the huge and important practical implications of the concept. It has long been recognized, for instance, that brand resilience (durability) is directly related and connected to corporate reputation. In this sense, corporate reputation encapsulates all the different facets of a marketing strategy, insofar, as the objective of every marketing program becomes to nourish and enhance a company's corporate reputation.

Nonetheless, corporate reputation proved to be an elusive and a difficult concept to define. To date, there appears to be no consensus as to what it really means among the many writers who have sought to define the term. Sociologists, accountants, organizational theorists, and marketers have all come up with their own definition of the concept. To a sociologist, for instance, corporate reputation indicates 'esteem or prestige', to an accountant 'goodwill', to an organization theorist 'identity' and to a marketer an 'image', (Wartick, 2002; Iwu-Egwuonwu, 2011).

Others sought to define the term by highlighting its differences from related concepts often taken as synonymous to corporate reputation; namely 'image' and 'identity'. Image' appears to indicate the perceptions of the company by its external stakeholders (mainly its customers), while 'identity' refers to the perceptions of the firm by its internal stakeholders i.e. employees, managers ...etc. Corporate reputation, according to these writers, becomes the aggregation of 'identity' and 'image' (reputation= image + identity) (William \& Barret, 2000).

That said, however, it is not hard to find some common threads that bind together the many efforts which have attempted a theoretical delimitation of the construct. Mainly that most of these definitions portrayed corporate reputation as a perceptual and an attitudinal concept. As one writer puts it, "reputation cannot be argued as anything but perceptual". Such perceptual nature of the concept, according to the writer "seems indisputable" (Wartick, 2002). A sample of some definitions that shared in this assertion may serve as a proof. Wartick (2002), for instance, in an earlier attempt defined corporate reputation as, "the aggregation of stakeholders' perceptions of how well organizational responses are meeting the demands and expectations of many stakeholders". (p. 156) To Fombrun (1990) the concept indicates "the perceptual representations of the company past actions and future prospects that describes the firm overall appeal to all of its key constituencies when compared with leading rivals" (p. 242). Likewise, Post and Griffin (1997) viewed corporate reputation as a "synthesis of the opinions, perceptions and attitudes of an organization's stakeholders" (p.156). To Bick et al. (2003) corporate reputation represents "the general view of the company" (p. 853) "the external stakeholders' perception about an organization" (Davis \& Miles, 1998; Hatchel \& Schulz, 2000), "a reflection of stakeholders" views about an organization overtime" (Saxton, 1998), the "lasting perception held of an organization by an individual group or network that forms a collective system of beliefs and opinions that influence people's actions with regard to an organization" (Banter, 2000), "an overall evaluation of the extent to which a firm is substantially 'good' or 'bad"' (Keh\&Yie, 2009).

So it appears that the vocabulary used to define corporate reputation and attitudes and perceptions looks very similar if not identical. This vocabulary reflects an evaluative predisposition toward some object that reflects certain cognitions (knowledge), feelings (evaluations or assessments) and intentions (readiness for action) (Shifman and Kanook, 2010). These cognitions, beliefs, feelings, intentions are what make-up an individual's attitudes and perceptions.

Perception is defined as a process by which an 'individual' interpret and organize the sensations he is exposed to, into a meaningful picture of the world (Buchanan \& Huziniski, 2010). It is a private understanding of reality based on "a series of beliefs about (stimuli)" On a social level, perception indicates the impression one has of a social stimulus or set of stimuli as conditioned by the individual own experience, needs and background (Schiff, 1970). This process follows three stages: a) exposure and awareness of a stimulus (sensation) (b) organization and (c) interpretation of such information. The result of these processes is a unique private picture of what is really out there (Schiffman \& Kanook, 2010). When we compare the semantics used to define perception to that of an attitude, the similarity is all the more striking. The dictionary definition of an attitude indicates "the way 
you think and feel about somebody or something". It is a predisposition, a tendency toward an attitude object. These feelings, predispositions, beliefs and intentions constitute an individual's "view of the world" (Campbell, 1963). In the final analysis, attitudes and perceptions become the collection of cognitions, beliefs, evaluations, feelings (affect) and intentions which predisposes an individual to react in a certain way toward the attitude object (Schiffman \& Kanook, 2010). The summation of these'perceptions' 'knowledge', 'evaluations', 'feelings' stakeholders hold about an organization relative to other competing organizations makes up the definition of corporate reputation and provides the essential aspects of our prospective measurement scale.

\subsection{The Generation of the Item Pool}

As stated earlier, the purpose of this cross-sectional study is to develop and validate a scale to measure the corporate reputation of Islamic banks. The relevant operational definition of the target domain draws mainly on its attitudinal and perceptual nature (Helm, 2007; Shamma, 2012). Given such a premise, corporate reputation is viewed as, "a synthesis of the opinions, perceptions, and attitudes of an organization's stakeholders' (Post \& Griffen, 1997). The constituent elements of the construct according to this definition include the perceptions, beliefs, feelings, and intentions stakeholders have toward Islamic banks. This section describes the steps taken to generate a pool of items that reflect these elements. That said, we were mindful of the fact that item generation is a lengthy and slow process. In essence, it is an iterative process involving several stages of item writing, rewriting, editing and conceptual and psychometric analysis (Clark \& Watson, 1995). The conventional wisdom to follow, here, is to start by a large number of items and then gradually reduce them to a practical few towards the latter stages of the process.

Bearing this in mind, a pool of 42 statements that reflect the semantic content of the construct domain was developed. This is done in consultation with a number of colleagues who are experts in research methodology in the College of Business, University of Bahrain, and after a comprehensive review of related literature on the concept of corporate reputation and the theoretical origins of Islamic finance. A Likert-Scale format provided the main research instrument. The scale usually measures levels of agreements/disagreements on a continuum ranging from strongly agree to strongly disagree. Respondents were to choose from a possible five responses including a neutral point of neither/nor. This particular format was preferred, in this case, because of its ease of use, familiarity and wider utilization in scale development.

In order to minimize acquiescent bias (Nunnly, 1967) i.e., the tendency of respondents to agree with a statement or to respond in the same way to items, a good mix of both positively/negatively worded items was used. Of the initial 42 items generated, 22 were positively worded compared to 20 statements that were negatively stated. It took between three to four months to come up with the whole battery of items. A process of item editing followed the generation of the item pool. Every single item was checked for its language, wording, relevance, adequacy and sequence.

\subsection{The Scale Face and Content Validity}

The next stage in the scale development process amounts to an assessment of the scale face and content validity. The two concepts are not the same. Face validity indicates whether the test 'looks like' or 'appears to be' a measure of the construct of interest. Content validity verifies whether the items included in the test are the right items to measure the construct and reflect its 'content'. Both measures, however, are subjective and based on the assessment of experts (Sufian, 2009). With this in mind, the items were given to a number of staff members in the college of Business, University of Bahrain to assess their relevance to the target domain and to have an informed and expert item selection. All items were checked for their salience, clarity and relevance. Ambiguous, loaded and double-barreled questions were either rewritten, or split into two. Some items were deleted altogether. Specifically, 13 statements were deemed irrelevant or inadequate to the measurement of the construct and were therefore eliminated from the analysis. 29 items are retained for further investigation. Out of these 16 items addressed the cognitive and perceptual component of the construct, 8 explored the affective dimension, and 5 statements addressed the conative component of the domain, i.e. the corporate reputation of Islamic banks. Appendix (A) shows the retained items.

\subsection{Data Collection}

Data collection took place between the months of March and June, 2013. The draft questionnaire was distributed by hand to a convenient sample of 150 individuals. These included students, administrative staff and staff members in the University of Bahrain. 109 filled questionnaires were returned. Out of these 3 questionnaires were discarded for reasons of either being incomplete or not appropriately filled. The actual sample size is therefore 106 . Of these $65 \%$ were females, $35 \%$ males. $54.7 \%$ were unmarried and $41.5 \%$ married. $22 \%$ have an account in Islamic bank, $49 \%$ in a conventional bank, and $27 \%$ have an account in both conventional and Islamic 
banks. Three quarters of the sample have a university degree and $15 \%$ possess a higher university degree. $38 \%$ of sample is under 30 years of age, $32 \%$ are between 30 and 40 years of age and $18 \%$ are from age cohort of 40 a

\subsection{Analysis: The Factorability of the Data}

The specific questions addressed by the data analysis process are: is the set of data at hand suitable for factor analysis? If so, what are the most salient components (subscales) that can be identified within the data set? And how reliable and valid these results are (their psychometrics)?

So it appears from these questions that factor analysis provided the key statistics used in the analysis. In essence, factor analysis is a data reduction tool. It has the merit of reducing a large number of factors into a more manageable few. What is in mind here are two, perhaps contradictory, objectives: to explain as much variance as possible within the model by using the minimum number of factors (Thurstone, 1956).

However, before identifying the factors (subscales) that the data may include, it is pertinent to make sure that the data is factorable. A set of data is deemed suitable for factor analysis if three conditions are met: (a) a sufficient number of meaningful relationships exist among the items the scale includes, i.e. how much variance in the item is explained by the factor (its communality); (2) the Kaiser-Meyer-Oklin Measure of Sampling adequacy (KMO) is 0.6 or above; (3) the Bartell Test of Sphericity value is significant (Pallant, 2011).

Hence, the 29 items which survived the face and content validity screening stage were factor analyzed. As alluded to above a set of data is regarded factorable if sufficient and meaningful relationships among the battery of items in the scale can be identified. This is normally reflected in the correlation coefficients matrix which lists all the coefficients of correlation among all of the items in the model. In this respect this is the Pearson correlations coefficient. Normally a coefficient of .3 or above is the minimum acceptable limit for the inclusion of a particular item in the factors making up the model.

A simple visual inspection of the full correlation matrix points to a substantial number of meaningful interrelationships among the various items in the scale that satisfied the minimum recommended coefficient (Appendix B).

The Kaiser-Meyer-Oklin Measure of Sampling Adequacy (KMO) and the Bartell Test of Sphericity do also point to a similar conclusion. Theoretically, a KMO value of .6 or above and a significant Bartell test of Sphericity indicate that the data is suitable for factor analysis. The value of the KMO is .892 , well above the recommended level, and the Bartell Test of Sphericity is significant (approx. Chi-square $=919.779 ; \mathrm{p}=.000$ ). In conclusion, the correlation matrix, the $\mathrm{KMO}$, and the Bartell test of sphericityall attest to the fact that the set of data at hand is factorable.

\subsection{The Factors Extracted}

Two statistical criteria were instrumental in determining how many salient and plausible factors to retain for further analysis; namelythe Kaiser Criterion and the Cattel Scree test (Cattel, 1966).

The Kaiser Criterion recommends that only items with higher factor loadings should be candidates for selection. Factor loadings, in turn, are reflected in the eigenvalues i.e. the contribution of each factor to total variance. For a factor to be extracted it must have an eigenvalue of one or more. Table 2 provides a summary of the total variance explained by all possible factors. As evident from the table, only the first three factors had eigenvalues equal to or greater than one; hence they account for most of the variance in the model. Together, the three factors explained $61.7 \%$ of the total variance. Factor one has 9 items in it and was the primary contributor to the explained variance. On its own this factor explained $43.5 \%$ of the overall variance. Factor two has eight items in it and explained $11.5 \%$ of the variance. Factor three has one item in it and explains $6.6 \%$ of variance. Twelve items loaded poorly on any one of the three factors extracted and were therefore eliminated from the analysis.

Table 2. The percentage of variance explained

\begin{tabular}{|c|c|c|c|c|c|c|}
\hline \multirow[t]{2}{*}{ Components } & \multicolumn{3}{|c|}{ Initial Eigenvalues } & \multicolumn{3}{|c|}{ Extraction Sums of Squared loadings } \\
\hline & Total & $\%$ of variance & Cumulative \% & Total & $\%$ of variance & Cumulative $\%$ \\
\hline Factor one & 7.391 & 43.477 & 43.477 & 7.391 & 43.477 & 43.477 \\
\hline Factor two & 2.650 & 11.478 & 55.152 & 2.650 & 11.478 & 55.152 \\
\hline Factor three & 1.518 & 6.572 & 61.725 & 1.518 & 6.572 & 61.725 \\
\hline
\end{tabular}

This solution is upheld by the Cattel Scree test which is a plot of the eigenvalues of the full correlations matrix. The number of the salient factors to retain is indicated by a change in the shape of the plot (the elbow) (Pallant, 
2011). Only factors above this point are considered in the solution. Beyond this point, however, factors contribute very little to total variance and as such would be excluded from the analysis. As shown in figure (1), the plot slopped steeply downwards at first and then leveled-off after the first three factors which corroborates the three-factor solution suggested by the Kasier criterion.

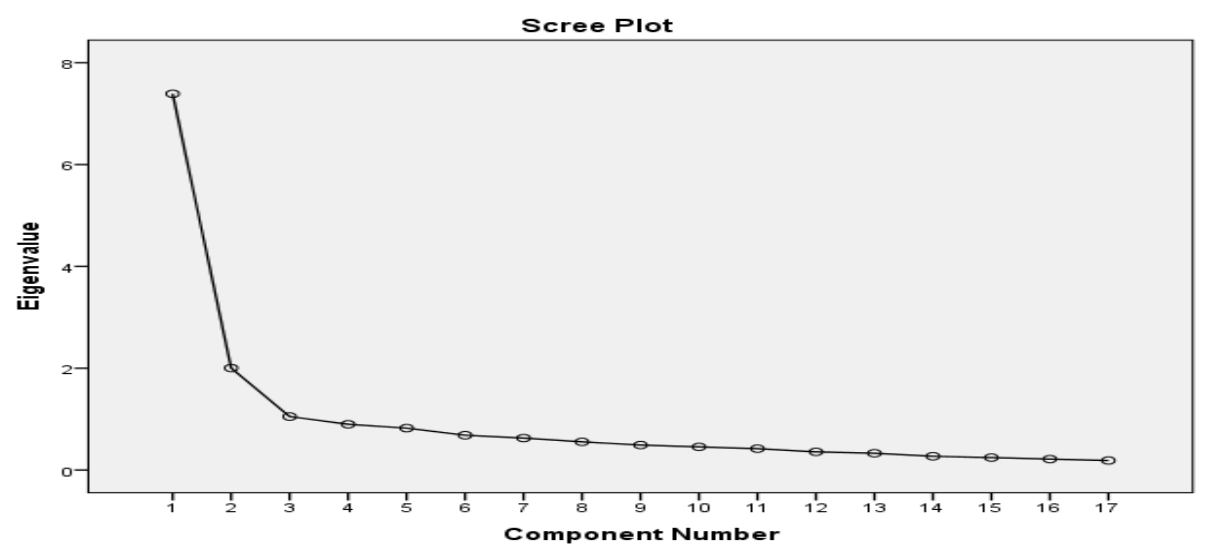

Figure 1. Eigenvalues plot

It must be noted, however, that factor three included only one item in it -I do not trust Islamic banks any more after what I heard and heard about them- which cross-loaded on factor two. Its loading on three is, however, negative and that on two is slightly less than the recommended.4 level. As the item shares the same language with the rest of the items in factor two, it was added to the battery of items making up this factor. Thus, the model becomes a two rather than a three-factor solution that explains $55 \%$ of factor variance and includes the most distinct and meaningful dimensions of the target construct. The 17 items making up the two factors would therefore constitute our scale for the measurement of corporate reputation of Islamic banks (table 3).

Table 3. Factor loadings and communalities

\begin{tabular}{|c|c|c|c|c|}
\hline \multicolumn{2}{|c|}{ Items } & \multirow{2}{*}{$\begin{array}{l}\text { Communality } \\
\text { (extracted) }\end{array}$} & \multirow[t]{2}{*}{ Loading } & \multirow[t]{2}{*}{ Loading } \\
\hline \multicolumn{2}{|c|}{ Factor one (positive statements): } & & & \\
\hline 1. & I get a sense of spiritual fulfillment when I deal with an Islamic bank. & .703 & .795 & \\
\hline 2. & Personally I will not deal with any bank unless it is an Islamic bank. & .581 & .790 & \\
\hline 3. & I am willing to pay a little bit extra for the services of an Islamic bank. & .714 & .789 & \\
\hline 4. & It means a lot to me to deal with an Islamic bank. & .735 & .781 & \\
\hline 5. & I prefer to deal with an Islamic rather than a conventional bank. & & .742 & \\
\hline 6. & It is important to me to be in a country in which there are Islamic banks. & .507 & .736 & \\
\hline 7. & I feel religiously obliged to do business with an Islamic bank. & .628 & .735 & \\
\hline 8. & In my opinion, Islamic banks play an important economic role in this country. & .499 & 672 & \\
\hline 9. & The emergence of Islamic banks on the world stage advances the cause of Islam. & .657 & .581 & \\
\hline 10. & Islamic banking was a landmark in regulating economic life according to the Islamic doctrine. & .586 & .400 & \\
\hline \multicolumn{2}{|r|}{ Factor Cronbach alpha coefficient } & .892 & & \\
\hline \multicolumn{5}{|c|}{ Factor two (negative statements): } \\
\hline 1. & In my opinion, Islamic banks use the name of Islam purely for profiteering. & .677 & & .847 \\
\hline 2. & The difference between an Islamic and a conventional bank is in name only. & .683 & & .756 \\
\hline 3. & Islamic banks sell Riba (Usury) to their customers under different labels. & .671 & & .751 \\
\hline 4. & The experience of Islamic banks was a minus rather than a plus on the nameof Islam. & .646 & & .662 \\
\hline 5. & In Islam, there is no such thing as an "Islamic bank". & .416 & & .558 \\
\hline 6. & All things considered, I am indifferent to have an account in an Islamic or a conventional bank. & .511 & & .442 \\
\hline & I do not trust Islamic banks any more after what I heard and read about them. & .665 & & .400 \\
\hline \multicolumn{2}{|r|}{ Factor Cronbach alpha coefficient } & .843 & & \\
\hline \multicolumn{2}{|c|}{ The overall scale Cronbach alpha coefficient } & .915 & & \\
\hline
\end{tabular}




\subsection{The Scale Reliability}

A measurement scale is said to be reliable if it exhibits some degree of internal consistency, i.e. the extent to which the items that make up the scale 'hung together' ... or measure the same underlying construct (Pallat, 2011). A conventional indicator of a scale internal consistency (reliability) is the Cronbach Alpha coefficient. A scale is deemed reliable if its alpha coefficient is equal to or above 7 (De Vellis, 2003).

Table (4) provides a summary of the Cronbach Alpha values of each of the two subscales and of the overall scale. As the alpha values indicate the corporate reputation scale of Islamic banks has good internal consistency. The first and second factors had Alpha co-efficient of .892 and .842 , respectively, way above the recommended .7 coefficient. The overall scale (factor one+ two) has also good internal consistency; with a Cronbach alpha coefficient of .915. In view of these results, it can be safely assumed that the corporate reputation scale - the 17 items- is reliable and internally consistent.

Table 4. The factor Cronbach Alpha coefficients

\begin{tabular}{lll}
\hline Components & No. of items & Alpha co-efficient \\
\hline Factor one & 10 & .892 \\
Factor two & 7 & .842 \\
The overall scale & 17 & .915 \\
\hline
\end{tabular}

\subsection{The Construct Validity}

Construct validity is an important and accepted concept in scale development. Traditionally, the concept is defined as, "the degree to which a test (a scale) measures what it claims or purports to measure" (Brown, 1996). Because of its multi-faceted nature, establishing construct validity is regarded as an ongoing process that requires an accumulation of evidence. Having said that, a number of strategies were used to demonstrate the validity of the measurement scale we are after. These included content analysis, the correlation matrix coefficients, the factor loading coefficients, the communalities, the variance extracted, and the Cronbach alpha coefficients. The evidence from all of these perspectives is convincing and point to the conclusion that the test is measuring an underlying construct, in this case the corporate reputation of Islamic banks.

\section{The Factors Interpretation: The Positive/negative Dichotomy}

As indicated earlier, the decision on how many factors to retain is guided by the criterion of 'simple structure' advocated by Thurston (1956). To get to such structure only items that have a minimum factor loading of .4 and a minimum Cronbach alpha coefficient of .6 were considered in the solution model.

\subsection{Factor \# 1 (The Positive Statements)}

This factor explained the largest proportion of total variance (43.5\%) in the model. Initially, it included nine items, with factor loadings ranging between .795 and .581 . However, item number 21 which reads -Islamic banks was a landmark in regulating economic life according to the Islamic doctrine-also cross-loaded on factor two, but retained for this factor because it is clearly in tune with the battery of positive statements about Islamic banking. This raised the total number of items in the subscale to ten all positively worded statements: hence the name of the factor. These statements addressed the perceptions, beliefs and intentions people hold toward Islamic banks. The resultant subscale demonstrated high internal consistency (reliability) with a Cronbach alpha coefficient of (.892), which suggests that this battery of items is tapping an underlying concept.

\subsection{Factor \#2 (The Negative Statements)}

This factor has 7 items in it all negatively worded. Together these items explain (11.5\%) of the total variance in the solution. The factor loadings range between .842 and .442 . The Cronbach alpha coefficient indicates a high internal consistency of the subscale (.843). Likewise, the overall scale (factor one + factor two) also demonstrates high internal consistency with an alpha coefficient of (.915) reflecting a high degree of homogeneity or coherence among the items making up the scale

The idea of Islamic banking is and will continue to be a controversial one even among Muslims. Opinions appear to be divided as to the merits and credibility of such a project. All in all, people seem to fall into three categories as to how they see and perceive the Islamic banking experience (Khalil, 2013). Group one, totally rejects the Islamic banking project and regards it contrary to the teachings and principles of Islam. To this group the word 'bank' itself is a western importation that is built around the notion of interest and as such bears no relationship to anything Islamic. Group two fully embraces and accepts the doctrine of Islamic banking and looks upon the 
theory and practice of Islamic banks as compatible with those of the Islamic faith. The third group occupies somewhat middle ground between the first and the second groups. On one hand, it accepts the theological underpinnings of Islamic banking but feels that some of the practices and operations of Islamic banks negate the basic tenets of Islam.

Against this background a plausible interpretation of the two factors solution can be suggested here. As a research topic, Islamic banking is a sensitive issue for most Muslims. Some of them would simply shy away to voice an opinion that seems critical of an emotionally laden concept like Islamic banking, even if they have one. This fact may have colored the sample perceptions of Islamic banks and impacted their answers to the scale items. Respondents who have a prior positive predisposition toward Islamic banks would most likely agree with the positive statements and at the same time disagree with the negatives ones. Others who have their reservations about the experiment may see the negative statements as a backdoor to express their views about Islamic banking without being unnecessary provocative. In other words, it becomes much easier for these respondents to agree with the battery of statements that are critical of Islamic banking rather than disagree with the positive ones. For the later i.e. the positive statements, they would rather abstain by checking on the neither/nor option than voice their outright disagreement. As a result of this we have a scale that is built around this positive/negative dichotomy: a two-factor solution.

\section{A Summary and Suggestions for Future Research}

The study described here represents an exploratory attempt to develop and validate a measurement scale to tap into the corporate reputation of Islamic banks. As a construct corporate reputations is thought to exhibit these attributes (a) it is the aggregate perceptions of all stakeholders, (b) it is comparative (c) it can be positive or negative (d) it is stable and enduring (Walker, 2010). Toward this end a 17-item scale was developed, verified and validated. The 17-items scale, suggested two factors to retain in the solution. On their own, these two factors contributed $55 \%$ to the total variance in the factor model. Factor one consists of ten positively-worded statements on the opinions, views, perceptions, beliefs, feelings and behavioral intensions the sample may have toward Islamic banks. Similarly, factor two includes 7 negatively-worded statements on how the sample members regard the corporate reputation of Islamic banks. A host of statistical tools and tests were used to verify the factorability of the data, and to discover the latent variables that underlie the scale.

While no efforts were spared to come up with a reliable and valid measure, it must be said, however, that the resultant scale reported here remains a provisional one. Additional studies are certainly needed to further verify other dimensions of the validity of the scale, mainly its predictive validity. In this respect, two important questions, in particular, need to be addressed: (a) How the scale compares to other similar measures like those of corporate 'image' and 'identity? And how the scale would discriminate among various groups with different personal characteristics such as age, gender, education and conventional/Islamic banks customers? These are interesting research questions worthyof a second academic investigation.

The venue for this study is the Kingdom of Bahrain. It is, therefore, possible for people in other Muslim countries to see Islamic banking in a different light. As such it will be interesting and theoretically valuable to validate the scale using a sample from other countries in the Muslim world. It would be intriguing, for instance, to see how people in the rest of the Gulf-region, north and sub-Saharan Africa and/or Asia view the experiment of Islamic banking.

One last point to mention is that for some Muslims it may be difficult to voice a negative opinion on a touchy and sensitive issue like Islamic banking. At best it makes them feel uncomfortable. This is evident from the sizable percentage of respondents who chose to tick the neutral option in the scale format for an answer. For these people the neither/nor option offers a safer response, some sort of a soft-landing, so to speak, to escape an otherwise difficult situation. This is both a possible limitation and a suggestion for future studies that may contemplate using the scale presented here to explore the corporate reputation of Islamic banking. The advice, here is to use a four rather than a five-point format. This may probably force respondents to answer the statement instead of dodging it by ticking the neutral option.

\section{References}

Ahmed, U. (2010). Challenges facing Islamic banking.

Al-faisal, A. (2008). Washington Post, Friday, October 31, pp.1-11 quoted in Ambach.

Al-Hamazani, M. (2008). Islamic banks Unaffected by Global Financial Crisis. Alsharq-Alawsat, 30/9/2008.

Ambah, S. F. (2008). Washington Post, Friday, October 31, pp.1-11. 
Balmer, J. M. T. (2001). Corporate identity, corporate reputation, and corporate marketing: seeing through the fog. European Journal of Marketing, 35(3/4), 248-291. http://dx.doi.org/10.1108/03090560110694763

Barnett, M., Jermier, J., \& Lafferty, B. (2006). Corporate Reputation: The Definitional Landscape. Corporate Reputation Review, 9(1), 26-38. http://dx.doi.org/10.1057/palgrave.crr.1550012

Bennett, R., \& Kottasz, R. (2000). Practitioner perceptions of corporate reputation: An empirical investigation. Corporate Communications: An International Journal, 5(4).

Bhatti, J. (2010). The Times (UK), June, 21.

Bick, G., Jacobson, M. C., \& Abratt, R. (2003). The corporate identity management process revisited. Journal of Marketing Management, 19, 835-855. http://dx.doi.org/10.1080/0267257X.2003.9728239

Brown, T., \& Dacin, P. A. (1997). The company and product. Journal of Marketing, 61(1), 68-84. http://dx.doi.org/10.2307/1252190

Buchanan, D., \& Huczynski, A. A. (2010). Organizational Behavior. London: FT.

Carter, S. M., \& Deephouse, D. L. (1999). Tough talkand soothing speech: managing reputations for being tough and for being good. Corporate Reputation Review, 2(4), 308-332. http://dx.doi.org/10.1057/palgrave.crr.1540089

Cattell, R. B. (1966). The Scree test for the number of factors. Multivariate Behavioral Research, 1, 245. http://dx.doi.org/10.1207/s15327906mbr0102_10

Chun, R. (2005). Corporate reputation: Meaning and measurement. International Journal of Management Review, 7(2), 91-109. http://dx.doi.org/10.1111/j.1468-2370.2005.00109.x

Churchill, G. A. (1979). A Paradigm for Developing Better Measures of Marketing Constructs. Journal of Marketing Research, 16(1), 64-73. http://dx.doi.org/10.2307/3150876

Clark, L. A., \& Watson, D. (1995). Constructing Validity: Basic Issues in Objective Scale Development. Psychological Assessment, 7(3), 309-319. http://dx.doi.org/10.1037/1040-3590.7.3.309

Clark, L. A., \& Watson, D. (1999). Temperament: A new paradigm for trait psychology (2nd ed., pp. 399-423). New York: Guilford Press.

Cronbach, L. J. (1951). Coefficient alpha and the internal structure of tests. Psychometrika, 16(3), 297-334. http://dx.doi.org/10.1007/BF02310555

Cronbach, L. J., \& Meehl, P. C. (1955). Construct validity in psychological tests. Psychological Bulletin, 52, 281-302. http://dx.doi.org/10.1037/h0040957

Davies, G., \& Miles, L. (1998). Reputation Management: Theory versus Practice. Corporate Reputation Review, 2(1), 16-28. http://dx.doi.org/10.1057/palgrave.crr.1540064

Dawood, M. (2008). Washington Post, Friday, October 31, pp.1-11quoted by Ambach.

De Vellis, R. F. (2003). Scale development; Theory and Measurement (2nd ed.). Second edition. Sage publications, Inc.

Donald, T., \& Campbell. (1963). Some Attitudes and Other Acquired Behavioral Disposition. In S. Koch (Ed.), Psychology: A Study of a Science. New York: McGraw-Hill.

Dusuki, A. W., \& Abdalla, W. (2006). The Ideal of Islamic Banking: Chasing a Mirage? A paper presented to the Islamic banking and Finance educational Colloquium, Bank Negara, Malaysia, Kuala Lumpur.

Eagle, L. (2010). Exporting Islamic banking from the Middle East, Bankers Academy Briefings. Thursday, January, 28.

Etzod, G. et al. (2011). Islamic Banking: Dawn of a New Era. IESE, Business Scholl, University of Navara.

Fombrun, C. J. (1996). Reputation: realizing value from the corporate image. Boston, MA: Harvard Business School Press.

Fombrun, C., Gardberg, N., \& Sever, J. (2001). The reputation quotient: a multi-stakerholdermeasure of corporate reputation. Journal of Brand Management, 7(4), 241-255. http://dx.doi.org/10.1057/bm.2000.10

Gait, H. A., \& Worthington, A. C. (2008). An empirical survey of individual consumer, business firms, and financial institutions attitudes towards Islamic Methods of finance. International Journal of Social Economics, 35(11), 783-808. http://dx.doi.org/10.1108/03068290810905423 
Gotsi, M., \& Wilson, A. (2001). Corporate reputation: Seeking a definition. Corporate Communications: An International Journal, 6(1), 24-30. http://dx.doi.org/10.1108/13563280110381189

Hassan, K. M., \& Lewis, K. M. (2007). Hanbook of Islamic Banking. Edward Elgar Publishing House, UK. http://dx.doi.org/10.4337/9781847205414

Hatch, M., \& Schultz, M. (2000). Scaling the tower of babel: relational differences between identity, image and culture in organizations. In M. Schuulz, M. Hatch, \& M. H. Larsen (Eds.), The Expresseive Organization (pp. 11-35). New York, NY: Oxford University Press.

Helm, S. (2007). One Reputation or many? Comparing stakeholders' perceptions of corporate reputation. Corporate Communications: An International Journal, 12(3), 238-254. http://dx.doi.org/10.1108/13563280710776842

Iqbal, Z., \& Mirkhor, A. (2013). Economic Development and Islamic Finance. Washington, DC: World Bank Publications.

Iwu-Egwuuonwu, R. C. (2011). Corporate Reputation and firm Performance: Empirical Literature Review. International Journal of Business and Management, 6(4), 197-206. http://dx.doi.org/10.5539/ijbm.v6n4p197

Khalil, S. M. (2013). The Theory and Practice of Islamic Banks: An Evaluation. Sudanile, an online newspaper.

Khan, M., \& Bhatti, M. I. (2009). Islamic Banking and Finance: on its way to globalization. Managerial Finance, 34(10), 708-725. http://dx.doi.org/10.1108/03074350810891029

Merriam-Webster. (2012). Retrieved from www.Merriam-Webster.com

Nasser, K., Jamal, A., \& Khalid, A. K. (1999). Islamic Banking: A study of customer satisfaction and preferences in Jordan.

Pallant, J. (2011). SPSS SURVIAVAL MANUAL: A step by step guide to data analysis using SPSS (4th ed.).

Post, J., \& Griffin, J. (1997). Corporate reputation and external Affairs Management. Corporate Reputation review, 1(1/2), 165-171. http://dx.doi.org/10.1057/palgrave.crr.1540038

Ranzini, S. L. (2007). Islamic Finance finally taking roots in North America. Islamic Finance News, 4(13), 1-10.

Saxton, M. K. (1998). Where Do Corporate Reputations Come From? Corporate Reputation Review, 1(4). http://dx.doi.org/10.1057/palgrave.crr.1540060

Schiff, R. M. (1970). Some theoretical aspects of attitudes and perception. Working Paper, National Hazard Research, University of Toronto.

Schiffman, L. G., \& Kanuk, L. L. (2001). Consumer Behavior (9th ed.). Pearson, New Jersey.

Shamma, M. H. (2012). Toward a Comprehensive Understanding of Corporate Reputation: Concept, Measurement and Implications. International Journal of Business and Management, 7(16), 151-169. http://dx.doi.org/10.5539/ijbm.v7n16p151

Sharif, Z. M. (2006). Islamic Finance in Australia. Islamic Finance News, 3(14), 11-12.

Thurstone, L. L. (1931). Measurement of social attitudes. Journal of Abnormal and Social Psychology, (26), 249-269. http://dx.doi.org/10.1037/h0070363

Thurstone, L. L. (1947). Multiple factor analysis. Chicago: University of Chicago Press.

Walker, K. (2010). A Systematic Review of the Corporate Reputation Literature: Definition, Measurement, and Theory. Corporate Reputation Review, 12(4), 357-387. http://dx.doi.org/10.1057/crr.2009.26

Wartick, L. S. (2002). Measuring Corporate Reputation, Definition and Data. Business \& Society, 41(4), 371-392. http://dx.doi.org/10.1177/0007650302238774

Williams, R., \& Barrett, D. J. (2000). Corporate philanthropy, criminal activity, and firm reputation: Is there a link? Journal of Business Ethics, 26(4), 341-350. http://dx.doi.org/10.1023/A:1006282312238

Willison, R. (2000). Challenges and opportunities in Islamic banking and Finance in the West: The United Kingdom Expereince. Islamic Economic Studies, 7(1\&2).

Zaman, M. R. (2002). Assessing the Nature and Impact of Islamic Banking and Finance. $2^{\text {nd }}$ International Conference on Banking and Finance (ICBF), August 9-11, 2002, Crete, Greece. 


\section{Appendix A}

\section{The Initial Item Pool}

Statements

1. In my opinion, Islamic banks play an important economic role in this country.

2. It means a lot to me to deal with an Islamic bank.

3. Personally, I will not deal with any bank unless it is an Islamic Bank.

4. Having an Islamic banking system is a noble idea, putting it in practice is a different matter.

5. It is important to me to be in a country in which there are Islamic banks.

6. I am willing to pay a little bit extra for the services of an Islamic bank.

7. Although the practices of some Islamic banks are not up to expectations, I prefer to deal with an Islamic rather than a conventional bank.

8. Occasionally, I become confused as to what an Islamic bank really means.

9. The difference between an Islamic and a conventional bank is in name only.

10. All things considered, it makes no difference to me to have an account in an Islamic or a conventional bank.

11. When I see the practices of some Islamic banks, I prefer, instead, to deal with conventional banks.

12. Compared to conventional banks, the rates charged by Islamic banks for their services are much higher.

13. A simple procedure like opening a bank account or getting some finance is more complicated and time consuming in an Islamic bank than a conventional one.

14. In the final analysis there is no such thing as an Islamic bank in islam.

15. I feel morally and religiously obliged to do business with an Islamic bank.

16. In my opinion, Islamic banks use the name of Islam purely for profiteering.

17. The quality of services provided by conventional banks is far superior to that of Islamic banks.

18. I get a sense of spiritual fulfillment when I deal with an Islamic bank.

19. Some people think that Islamic banks do not observe Sharia principles in their financial transactions.

20. The emergence of Islamic banking on the world stage advances the cause of Islam.

21. The experience of Islamic banking was a minus rather than a plus on the name of Islam.

22. I am lucky to be a witness to the rapid expansion and acceptance of Islamic banking worldwide during my lifetime.

23. Islamic banking was a landmark in the application of Islamic principles to economic life.

24. Islamic banks sell Reba (usury) to customers under different labels.

25. People like me regard Islamic banks as custodians of wealth on behalf of God.

26. Islamic banks see their customers as partners rather than clients.

27. On the decisions they take, Islamic banks serve the interests of society.

28. Compared to conventional banks, Islamic banks provide a much narrower range of services.

29. I do not trust Islamic banks anymore after what I heard and read about them.

A five-point Likert-scale format is used, ranging from strongly agree to strongly disagree with a neutral point.

\section{Appendix B}

\section{Interitem Correlation Matrix}

\begin{tabular}{|c|c|c|c|c|c|c|c|c|c|c|c|c|c|c|c|c|c|c|c|c|c|c|c|c|c|c|c|c|c|}
\hline $\mathrm{V}$ & 1 & 3 & 2 & 4 & 5 & 6 & 7 & 8 & 9 & 10 & 11 & 12 & 14 & 18 & 20 & 19 & 17 & 25 & 24 & 23 & 29 & 28 & 27 & 26 & 22 & 21 & 16 & 15 & 13 \\
\hline 1 & 1.0 & .42 & .60 & .17 & .41 & .26 & .44 & .44 & .46 & .24 & .06 & .16 & .53 & .45 & .18 & .49 & .19 & .14 & .55 & .31 & .25 & .17 & .34 & .04 & .29 & .43 & .05 & .27 & .29 \\
\hline 3 & .42 & 1.0 & .63 & .13 & .47 & .14 & .51 & .36 & .45 & .17 & .16 & .03 & .57 & .58 & .28 & .39 & .02 & .18 & .61 & .29 & .22 & .24 & .24 & .04 & .19 & 36 & .19 & .15 & .18 \\
\hline 2 & .60 & .63 & 1.0 & .23 & .55 & .15 & .63 & .40 & .53 & .12 & .13 & .08 & .60 & .68 & .28 & .58 & .18 & .14 & .74 & .47 & .14 & .27 & .29 & .08 & .44 & .58 & .16 & .36 & .44 \\
\hline 4 & .17 & .13 & .23 & 1.0 & .11 & 19 & .09 & .07 & .18 & .07 & .06 & .05 & .33 & .22 & .12 & .41 & .17 & .07 & .27 & .17 & .13 & .24 & .19 & .07 & .27 & .31 & .13 & .18 & .14 \\
\hline 5 & .41 & .47 & .55 & .11 & .10 & 02 & 49 & 26 & .33 & .10 & .16 & $0 ?$ & .38 & .57 & .18 & 38 & .10 & 16 & 55 & 30 & .15 & .13 & .34 & 01 & 19 & .39 & 08 & .24 & .24 \\
\hline 6 & .26 & .14 & .15 & .19 & .02 & 1.0 & .00 & .25 & .13 & .24 & .11 & .05 & .19 & .19 & .14 & .06 & .17 & .03 & .11 & .10 & .23 & .16 & .11 & .05 & .21 & .08 & .09 & .17 & .28 \\
\hline 7 & .44 & .51 & .63 & .09 & .49 & .00 & 1.0 & .19 & .40 & .19 & .04 & .05 & .46 & .55 & .17 & .30 & .00 & .19 & .61 & .39 & .24 & .10 & .36 & .02 & .25 & .30 & .15 & .21 & .27 \\
\hline 8 & .44 & .36 & .40 & .08 & .26 & .25 & .18 & 1.0 & .45 & .26 & .06 & .07 & .27 & .36 & .03 & .32 & .17 & .04 & .48 & .49 & .22 & .13 & .26 & .01 & .35 & .29 & .00 & .41 & .46 \\
\hline 9 & .46 & .45 & .53 & .18 & .33 & .13 & .40 & .45 & 1.0 & .29 & .11 & .19 & .47 & .49 & .29 & .47 & .14 & .15 & .45 & .51 & .26 & .18 & .27 & .10 & .49 & .46 & .11 & .34 & .31 \\
\hline 10 & .24 & .18 & .12 & .17 & .10 & .24 & .19 & .26 & .29 & 1.0 & .30 & .13 & .07 & .18 & .14 & .08 & ,25 & .01 & .18 & .27 & .27 & .22 & .10 & .06 & .22 & .05 & .06 & 31 & .08 \\
\hline 11 & .05 & .16 & .13 & .06 & .16 & .11 & .04 & .06 & .11 & .30 & 1.0 & .54 & .16 & .15 & .02 & .01 & .22 & .02 & .10 & .20 & .01 & .15 & .10 & .19 & .09 & .05 & .26 & .31 & .04 \\
\hline 12 & .16 & .03 & .08 & .05 & .02 & .05 & .05 & .07 & .19 & .13 & .54 & 1.0 & .02 & .01 & .09 & .11 & .12 & .13 & .05 & .19 & .15 & .22 & .09 & .22 & .17 & .09 & .35 & .19 & .09 \\
\hline 14 & .53 & .57 & .60 & .33 & .38 & .19 & .46 & .27 & .47 & .07 & .16 & .02 & 1.0 & .66 & .21 & .56 & .11 & .25 & .55 & .29 & .23 & .25 & .31 & .06 & .35 & .53 & .06 & .13 & .32 \\
\hline 18 & .45 & .58 & .68 & .22 & .57 & .19 & .55 & .36 & .49 & .18 & .15 & .01 & .66 & 1.0 & .23 & .61 & .14 & .16 & .69 & .44 & .21 & .33 & .37 & .00 & .40 & .47 & .09 & .28 & .37 \\
\hline 20 & .18 & .28 & .28 & .12 & .18 & .14 & .17 & .03 & .29 & .14 & .02 & .09 & .21 & .23 & 1.0 & .23 & .13 & .16 & .24 & .18 & .15 & .13 & .17 & .22 & .18 & .21 & .06 & .02 & .14 \\
\hline 19 & .49 & .39 & .58 & .41 & .38 & .06 & .30 & .32 & .47 & .08 & .01 & .11 & .56 & .61 & .23 & 1.0 & .14 & .17 & .56 & .36 & .07 & .39 & .24 & .09 & .39 & .60 & .07 & .26 & 36 \\
\hline 17 & .19 & .02 & .19 & .17 & .10 & .17 & .00 & .17 & .14 & .25 & .22 & .12 & .11 & .14 & .13 & .14 & 1.0 & .08 & .09 & .26 & .09 & .35 & .11 & .29 & .14 & .13 & .27 & .33 & .26 \\
\hline 25 & .14 & .18 & .14 & .07 & .16 & .03 & .19 & .04 & .15 & .01 & .02 & .13 & .25 & .16 & .10 & .17 & .08 & 1.0 & .25 & .01 & .30 & .29 & .05 & .18 & .09 & .16 & .14 & .13 & .11 \\
\hline 24 & .55 & .61 & .74 & .23 & .55 & .11 & .61 & .48 & .45 & .18 & .10 & .05 & .55 & .69 & .24 & .56 & .09 & .25 & 1.0 & .48 & .22 & .23 & .39 & .02 & .34 & .51 & .09 & .33 & .39 \\
\hline 23 & .31 & .29 & .47 & .17 & .30 & .20 & .39 & .49 & .51 & .27 & .20 & .19 & .29 & .44 & .18 & .36 & .26 & .01 & .48 & 1.0 & .24 & .34 & .38 & .17 & .58 & .51 & .16 & .57 & .46 \\
\hline 29 & .24 & .22 & .14 & .13 & .15 & .23 & .24 & .22 & .26 & .27 & .01 & .15 & .23 & .21 & .15 & .07 & .09 & .30 & .22 & .24 & 1.0 & .10 & .25 & .16 & .18 & .19 & .14 & .19 & .10 \\
\hline 28 & .17 & .24 & .27 & .24 & .13 & .16 & .10 & .13 & .18 & .22 & .15 & .22 & 25 & .33 & .13 & .39 & .35 & .29 & .23 & .34 & .10 & 1.0 & .10 & .26 & .48 & .33 & .17 & .42 & .27 \\
\hline 27 & .34 & .24 & .29 & .19 & .34 & .11 & .36 & .26 & .27 & .10 & .10 & .09 & .31 & .37 & .17 & .24 & .11 & .05 & .39 & .38 & .25 & .10 & 1.0 & .05 & .29 & .41 & .09 & .23 & .27 \\
\hline 26 & .04 & .04 & .08 & .07 & .01 & .05 & .022 & .01 & .09 & .06 & .19 & .22 & .06 & .00 & .22 & .09 & .29 & 18 & .02 & .17 & .16 & .26 & .05 & 1.0 & .23 & .16 & .19 & .14 & .12 \\
\hline 22 & .29 & .19 & .44 & .27 & .19 & .21 & .25 & .35 & .50 & .22 & .09 & .17 & .35 & .40 & .18 & .39 & .14 & .09 & .34 & .58 & .18 & .48 & .29 & .29 & 1.0 & .54 & .03 & .51 & .38 \\
\hline 02 & .43 & .36 & .58 & .31 & .38 & .08 & .30 & .29 & .46 & .05 & .05 & .09 & .53 & .47 & .21 & .60 & .13 & .16 & .51 & .51 & .19 & .33 & .41 & .16 & .54 & 1.0 & .06 & .44 & .42 \\
\hline 16 & .05 & .19 & .16 & .13 & .09 & .09 & .15 & .00 & .11 & .06 & .26 & .35 & .06 & .07 & .06 & .07 & .27 & .14 & .09 & .16 & .14 & .17 & .09 & .19 & .03 & .06 & 1.0 & 23 & .17 \\
\hline 15 & .26 & .15 & .36 & .18 & .24 & .17 & .21 & .41 & .34 & .31 & .31 & .19 & .13 & .28 & .02 & .26 & .33 & .13 & .33 & .57 & .19 & .42 & .23 & .14 & .51 & .44 & .23 & 1.0 & .46 \\
\hline 13 & .29 & .18 & .44 & .14 & .24 & .28 & 27 & .46 & .31 & .08 & .04 & .09 & .32 & .37 & .14 & .36 & .26 & .11 & .39 & .46 & .10 & .27 & .27 & .12 & .38 & .42 & .17 & .46 & 1.0 \\
\hline
\end{tabular}

V stands for variable; Bold numbers indicate a co-efficient equal to or greater than; All correlations are Pearson correlation coefficient. 


\section{Copyrights}

Copyright for this article is retained by the author(s), with first publication rights granted to the journal.

This is an open-access article distributed under the terms and conditions of the Creative Commons Attribution license (http://creativecommons.org/licenses/by/3.0/). 